\title{
Depressive disorder and psychosocial indicators in high school and college students from Mexico City: data from two censuses
}

\author{
Catalina González-Forteza, ${ }^{\prime}$ Cuauhtémoc Solís Torres, ${ }^{2}$ Francisco Juárez García, ${ }^{\prime}$ Alberto Jiménez Tapia, \\ Gisela Hernández Fernández, ${ }^{2}$ Héctor Fernández-Varela Mejía, ${ }^{2}$ María Elena Medina-Mora
}

Dirección de Investigaciones Epidemiológicas y Psicosociales, Instituto Nacional de Psiquiatría Ramón de la Fuente Muñiz. Ciudad de México, México.

2 Dirección General de Atención a la Salud, Universidad Nacional Autónoma de México. Ciudad de México, México.

\section{Correspondence:}

Alberto Jiménez Tapia

Dirección de Investigaciones Epidemiológicas y Psicosociales, Instituto Nacional de Psiquiatría Remón de la Fuente Muñiz Calzada México-Xochimilco 101 San Lorenzo Huipulco,

Tlalpan, 14370

Ciudad de México, México.

Phone: 554160 - 5179

Email: alberi@imp.edu.mx

Received: 17 January 2019 Accepted: 25 September 2019

\section{Citation:}

González-Forteza, C., Solís Torres, C., Juárez García, F., Jiménez Tapia, A. Hernández Fernández, G., Fernández-Varela Mejía, H., \& Medina-Mora, M. E. (2019). 'Depressive disorder and psychosocial indicators in high school and college students from Mexico City: data from two censuses. Salud Mental, 42(5), 243-249.

DOI: $10.17711 /$ SM. $0185-3325.2019 .031$

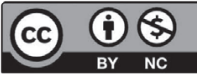

\begin{abstract}
Introduction. Almost 5\% of the Mexican general population (18-65 years old) has suffered depression once in their lives, and $2 \%$ of them more than once without receiving treatment. Objetive. To measure the prevalence of depressive disorder and to calculate its relationship with psychosocial indicators. Method. Data were collected through two censuses with high school and college students from a university in Mexico City $(n=116214)$. Participants completed the CES-D and other scales. Multivariate logistic regression models were used. Results. The prevalence of depressive disorder was $16 \%$. Predictors of depressive disorder were: having suffered psychological or sexual violence, having a family member who had been injured during an assault, history of depression in the family, poor quality in family and social relationships, among others. Discussion and conclusion. The prevalence of depressive disorder increases with age. As prevention and treatment at an early age are essential, intervention and monitoring strategies must be created and systematized taking gender and other elements into account, such as the relationship with the parents, violence, and a history of depression in the family.
\end{abstract}

Keywords: CES-D, depressive disorder, students, prevention, psychosocial indicators, prevalence.

\section{RESUMEN}

Introducción. Casi el 5\% de la población general de México (18-65 años) ha sufrido depresión una vez en su vida y $2 \%$ la ha sufrido más de una vez sin haber recibido tratamiento. Objetivo. Medir la prevalencia del trastorno depresivo y calcular su relación con algunos indicadores psicosociales. Método. Los datos fueron recolectados por medio de dos censos con estudiantes de bachillerato y de licenciatura en la Ciudad de México $(n=116214)$. Los participantes completaron el CES-D y otras escalas. Se usaron modelos de regresión logística multivariable. Resultados. La prevalencia del trastorno depresivo fue del $16 \%$. Los predictores del trastorno depresivo fueron: haber sufrido violencia psicológica o sexual, tener un miembro de la familia que hubíera sido herido durante un asalto, antecedentes de depresión en la familia, mala calidad en las relaciones familiares y sociales, entre otros. Discusión y conclusión. La prevalencia del trastorno depresivo aumenta con la edad. Como la prevención y el tratamiento a una edad temprana son esenciales, se deben crear y sistematizar estrategias de intervención y monitoreo que tomen en cuenta el género y otros elementos, como la relación con los padres, violencia e historia de depresión en la familia.

Palabras clave: CES-D, trastorno depresivo, estudiantes, prevención, indicadores psicosociales, prevalencia. 


\section{INTRODUCTION}

The Encuesta Nacional de Epidemiología Psiquiátrica (National Survey on Psychiatric Epidemiology) established a $4.8 \%$ general prevalence of having suffered depression at least once in life among Mexican adults (18-65 years old), $2.6 \%$ in men and $6.8 \%$ in women (Medina-Mora et al., 2003). Different studies also report that depressive symptoms and depressive syndrome are consistently more prevalent among young women than among young men (Fouilloux et al., 2013; Jaureguizar, Bernaras, Soroa, Sarasa, \& Garaigordobil, 2015; Twenge, Joiner, Rogers, \& Martin, 2018).

There are reports that $2.0 \%$ of the population experiences depression during childhood or adolescence, with an average of seven episodes in their lifetime, during which they do not receive treatment (Benjet, Borges, Medina-Mora, Fleiz, \& Zambrano, 2004). It is also known that during adolescence and youth several conditions appear, sometimes simultaneously with depression (Hankin, 2008) or depressive disorder; this disorder can occur alone or with another psychopathology (Angold, 1988). This situation may be related to neurobiological and psychological changes observed during adolescence or be a part of a more complex illness combined with other disorders (Adkins, Wang, Dupre, Van den Oord, \& Elder, 2009).

Different factors have been found to correlate and explain the probability of suffering depression or to present depressive symptoms or depressive disorder. These factors also make more complicated to treat the problem and increase the risk of other problematic behavior, in addition to causing disability (Wu, Hoven, Okezie, Fuller, \& Cohen, 2008). Some of these factors are: family low income (Hasin, Goodwin, Stinson, \& Grant, 2005), family history of depression and alcohol abuse (Anda et al., 2002; Olfson, Marcus, Druss, Pincus, \& Weissman, 2003), early experiences of violence (Reinherz, Paradis, Giaconia, Stashwick, \& Fitzmaurice, 2003; Castillo-Manzano, \& Arankowsky-Sandoval, 2008), having suffered physical or sexual abuse (Chapman et al., 2004), and excessive tobacco, alcohol or illegal drugs use (Martini, Wagner, \& Anthony, 2002; Lenz, 2004; Milani, Parrott, Turner, \& Fox, 2004).

Analyzing the above factors in a specific population, such as high school and undergraduate students, including and analysis by sex to explore if these elements have a differential manifestation that could be explained from a gender-based perspective, offers the possibility of detecting specific risk situations or another problems at early stages of life. Since students belong to a captive population, this facilitates the design and implementation of focused interventions that may be include a gender component, its evaluation and monitoring throughout the academic career of the students. The objectives of this article were: 1 . to measure the prevalence of depressive disorder at each of the two educational levels by sex, and 2 . to calculate the relation between indicators of violence, family history of chronic illness and alcoholism, family relationships, and perception of economic situation with depressive disorder by educational level and sex.

\section{METHOD}

\section{Study design and subjects}

This paper presents an analysis of data obtained from two censuses (2009 and 2010). The censuses were carried out with high school and undergraduate freshmen students in a public university from Mexico City. This work included 116214 students; 112306 (96.6\%) completed the information for the CES-D scale and for the other psychosocial indicators (violence, family relationship, and history of illness and alcoholism); 53170 (47.3\%) of the participants were men and $59136(52.6 \%)$, women (Table 1); the age ranged from 14 to 24 years old $(\overline{\mathrm{x}}=16.9 \pm 2.2)$. The majority lived in homes with between one and four members $(55.4 \%) ; 86.0 \%$ reported that their fathers worked and $59.4 \%$ that their mothers did; $79.7 \%$ lived with both parents and $17.9 \%$ with only their mother.

\section{Places}

The study took place in every middle high level and high education campus from the Universidad Nacional Autónoma de México. We collected data from 14 high schools and 22 schools and departments.

\section{Measures}

Depressive disorder: This was measured using the CES-D, a 20-item questionnaire designed to assess depressive symptoms (Radloff, 1977) in a self-report format to investigate the presence and persistence of depressive symptoms in the previous week. The cut-off point to establish the pres-

Table 1

Population characteristics by educational level and sex

\begin{tabular}{|c|c|c|c|c|c|c|}
\hline & \multicolumn{2}{|c|}{$\begin{array}{c}\text { High school } \\
n=57157 \\
(50.9 \%)\end{array}$} & \multicolumn{2}{|c|}{$\begin{array}{c}\text { College } \\
n=55149 \\
(49.1 \%)\end{array}$} & \multicolumn{2}{|c|}{$\begin{array}{c}\text { Total } \\
n=112306\end{array}$} \\
\hline & $n$ & $\%$ & $n$ & $\%$ & $n$ & $\%$ \\
\hline Class of 2009 & 27834 & 48.7 & 27905 & 50.6 & 55739 & 49.6 \\
\hline Class of 2010 & 29323 & 51.3 & 27244 & 49.4 & 56567 & 50.4 \\
\hline Men & 27749 & 48.5 & 25421 & 46.1 & 53170 & 47.3 \\
\hline \multirow[t]{2}{*}{ Women } & 29408 & 51.5 & 29728 & 53.9 & 59136 & 52.7 \\
\hline & Average & $D E$ & Average & $D E$ & Average & $D E$ \\
\hline Age & 15.1 & .9 & 18.8 & 1.4 & 16.9 & 2.2 \\
\hline
\end{tabular}


ence of depressive disorder was 16 (mean score plus a standard deviation), in accordance with an earlier validity study (González-Forteza et al., 2011).

Physical violence: This was measured using three items to determine whether the students had been beaten at home, school, and/or in their neighborhood. A two-option response format: yes/no, was used.

Psychological violence: Three items were used to register if the students had suffered violence in the form of insults or humiliations at home, school and/or in their neighborhood. Again, a two-option response format: yes/no, was used.

Sexual violence: Response to the question: Have you ever been raped or sexually abused? Two-option response format: yes/no.

Assault of relative who has been injured: This was measured using the following question: Has any of your family members ever been injured in a robbery? Two-option response format: yes/no.

Family history of alcoholism and depression: This was determined using data provided by students on whether any of their family members (father, mother, and/or siblings) had suffered these health problems. Two-option response format: yes/no.

Family and social relationships: Students were asked about their perception of the quality of their personal relationships most of the time, with their relatives (father, mother, siblings - four items) and other members of their social network (teachers, friends, neighbors - three items). Response options: very good, good, indifferent, bad.

Family support: This was measured using a scale of five items to report the frequency (always, almost always, sometimes, never) with which students spend time with their family, if they express what they want, if they ask for help, if they solve their problems, and if they share domestic chores and responsibilities with other family members.

Perception of economic situation: This was measured using the following sentence: Do you consider your family's economic situation to be: very good, good, average, bad, very bad.

Spare time: This was measured using a question on their amount of spare time after having finished their homework and domestic chores: 1-2, 3-4 or more hours.

Physical activity/intense exercise: This was measured with the question: Do you exercise intensely for at least 30 minutes, at least three times a week? Options: yes/no.

\section{Procedure}

Data were obtained from the 2009 and 2010 censuses performed at a large university, which used the Examen Médico Automatizado ([EMA] Automatized Medical Exam), a tool designed by a multidisciplinary group in the Dirección de Servicios Médicos de la Universidad Nacional Autónoma de México (DGSM-UNAM) (Head Office of Medical
Services at the National University of Mexico) to gather information on the physical and mental health, family, and environment of each student. Data obtained allowed for the creation of a vulnerability diagnosis with predictive profiles to treat or refer the students who require specialized attention and to support research promoting health-care (González-Forteza et al., 2011).

\section{Data analysis}

The database was built using UNAM's EMA Report Integration System, and SPSS version 18 (IBM SPSS, 2010) and BRIO version 7.0 were used to administer the databases and to do the data analysis.

Descriptive analyses were computed, and multivariate logistic regression models were developed to measure the association between depressive disorder and the psychosocial indicators of violence, family history of depression and alcoholism, family and social relationships, family support, perception of economic situation, spare time, and physical activity in each educational level, class, and sex. The frequency of depressive disorder by educational level, class, and sex, as well as their confidence interval, were calculated using the Stata software version 11 (Stata Corp, 2009).

\section{Ethical considerations}

In each EMA application session, participants were informed that all data they provided would be integrated into their clinical records and that its use and administration complied with the Norma Oficial Mexicana para Archivos Clínicos (Mexican Official Norm for Clinical Files, NOM168-SSA1-1998), which states that the information contained in clinical records must be handled with discretion and confidentiality, and that it will be used exclusively for medical, teaching, and research purposes. The use of EMA was approved by the Ethical Research Committee for the Macro-Project Developing New Models for the Prevention and Treatment of Addictive Behavior at the Universidad Nacional Autónoma de México (UNAM) on 3 July 2007.

\section{RESULTS}

The prevalence of depressive disorder was $16 \%$ in this population. Men at college presented a higher prevalence of depressive disorder than those at high school; in the case of women there were no differences based on educational level. However, at both educational levels, women presented significantly higher prevalence than men (Table 2).

The logistic regression analyses showed a similarity in the predictors of depressive disorder for men and women of both educational levels. The common predictors in the four groups were as follows: having suffered psychological or 
Table 2

Frequency of depressive disorder (CES-D, CUT-OFF $\geq 16$ ) by educational level and sex

\begin{tabular}{lccc}
\hline & $n$ & $\%$ & $95 \% \mathrm{Cl}$ \\
\hline Men at high school & 27749 & 10.38 & {$[10.020,10.738]$} \\
Men at college & 25421 & 13.00 & {$[12.584,13.411]$} \\
Women at high school & 29408 & 19.09 & {$[18.637,19.536]$} \\
Women at college & 29728 & 19.37 & {$[18.923,19.822]$} \\
High school students & 57157 & 14.86 & {$[14.567,15.151]$} \\
College students & 55149 & 16.43 & {$[16.124,16.743]$} \\
Men total & 53170 & 11.63 & {$[11.361,11.906]$} \\
Women total & 59136 & 19.23 & {$[18.914,19.549]$} \\
Total & 112306 & 15.63 & {$[15.422,15.847]$} \\
\hline
\end{tabular}

sexual violence, having a family member who had been injured during an assault, history of depression in the family, poor family relationship, and social relationships, perception of economic situation (ranging from average to bad), little support from the family, and lack of physical activity or intense exercise (Tables 3 and 4).

Other variables had a significantly greater impact. For instance, having suffered psychological and sexual violence increased the probability of depressive disorder between 2 and 2.5 times in the four groups. Other indicators had a differential prediction weight for men and women: having little spare time was a predictor only for men of both educational levels $(\mathrm{OR}=1.305$ and 1.401) (Table 3), while having suffered physical violence was a predictor only for women $(\mathrm{OR}=1.296$ and $\mathrm{OR}=1.443)$ (Table 4).

\section{DISCUSSION AND CONCLUSION}

This paper had two objectives: first to measure the prevalence of depressive disorder among students, and second to calculate the relation between indicators of violence, family history of chronic illnesses and alcoholism, family relationships and perception of economic situation at each educational level with depressive disorder, broken down by sex and educational level. Regarding the first objective, we found that the prevalence of current depressive disorder (during the previous week to the census) was almost twice as higher in women than in men: $19.23 \%$ and $11.63 \%$, respectively. Moreover, it was also more frequent among college students. These results concur with those reported in Mexican and international literature on the higher frequencies of depressive problems among young women (Ge, Conger, \& Elder, 2001; Benjet et al., 2004; Poulin, Hand, Boudreau, \& Sandor, 2005; Benjet et al., 2009), and show that the prevalence of depressive disorder tends to grow with age among this population of students, which could posit the risk of becoming lifelong and increasing because of the lack of prompt detection and treatment (Medina-Mora et al., 2005).

Since depressive problems have proven to be an issue among young people (Angold, Erkanli, Silberg, Eaves, \& Costello, 2002), to study them at this stage is relevant to know the development of symptoms and various risk factors. Depressive problems can also be pointed as a public health problem (Avanci, Assis \& Oliveira, 2008) that may be due to developmental biological variations or problematic circumstances that young people cannot face because they lack the necessary skills. In any case, the presence of depressive symptoms can become the origin of a disorder that, if not addressed, could lead to a disabling mental illness that implies a high cost to these individuals. This points out the importance of prevention and treatment at an early stage and the necessity for gender-oriented intervention and monitoring strategies, which must be created and systematized based on the consistent differences found by

Table 3

Predictors of depressive disorders among men at high school and college

\begin{tabular}{|c|c|c|c|c|c|c|}
\hline & \multicolumn{3}{|c|}{ Men at high school } & \multicolumn{3}{|c|}{ Men at college } \\
\hline & OR & $p$ & $95 \% \mathrm{Cl}$ & OR & $p$ & $95 \% \mathrm{Cl}$ \\
\hline Psychological violence & 2.641 & .000 & {$[2.299,3.034]$} & 2.204 & .000 & {$[1.904,2.552]$} \\
\hline Sexual violence & 2.294 & .054 & {$[.986,5.337]$} & 2.440 & .002 & {$[1.396,4.262]$} \\
\hline Assault of a family member who suffered injury & 1.283 & .001 & {$[1.109,1.485]$} & 1.289 & .000 & {$[1.120,1.482]$} \\
\hline Family history of depression & 1.061 & .517 & {$[.887,1.268]$} & 1.383 & .000 & {$[1.169,1.637]$} \\
\hline Family relationships & 2.166 & .000 & {$[1.895,2.475]$} & 1.620 & .000 & {$[1.416,1.852]$} \\
\hline Social relationships & 1.649 & .000 & {$[1.447,1.879]$} & 1.784 & .000 & {$[1.560,2.039]$} \\
\hline Family support & 1.218 & .000 & {$[1.170,1.268]$} & 1.216 & .000 & {$[1.170,1.264]$} \\
\hline Perception of economic situation & 1.209 & .004 & {$[1.062,1.375]$} & 1.202 & .009 & {$[1.047,1.380]$} \\
\hline Spare time & 1.305 & .000 & {$[1.132,1.504]$} & 1.401 & .000 & {$[1.232,1.595]$} \\
\hline \multirow[t]{2}{*}{ Physical activity/intense exercise } & 1.301 & .001 & {$[1.117,1.515]$} & 1.348 & .000 & {$[1.185,1.535]$} \\
\hline & \multicolumn{3}{|c|}{$\begin{array}{c}\chi^{2}=6.297, p>.05 \\
\text { Prediction: negative }=94.8 \%, \\
\text { positive }=24.3 \% \text {, total }=78.6 \%\end{array}$} & \multicolumn{3}{|c|}{$\begin{array}{l}\qquad \chi^{2}=6.297, p>.05 \\
\text { Prediction: negative }=92.9 \%, \\
\text { positive }=31.2 \% \text {, total }=75.2 \%\end{array}$} \\
\hline
\end{tabular}


Table 4

Predictors of depressive disorders among women at high school and college

\begin{tabular}{|c|c|c|c|c|c|c|}
\hline & \multicolumn{3}{|c|}{ Women at high school } & \multicolumn{3}{|c|}{ Women at college } \\
\hline & OR & $p$ & $95 \% \mathrm{Cl}$ & OR & $p$ & $95 \% \mathrm{Cl}$ \\
\hline Physical violence & 1.296 & .004 & {$[1.089,1.542]$} & 1.443 & .000 & {$[1.199,1.737]$} \\
\hline Psychological violence & 2.319 & .000 & {$[2.053,2.618]$} & 1.994 & .000 & {$[1.750,2.273]$} \\
\hline Sexual violence & 2.440 & .000 & {$[1.625,3.662]$} & 1.831 & .000 & {$[1.382,2.426]$} \\
\hline Assault of a family member who suffered injury & 1.294 & .000 & {$[1.154,1.451]$} & 1.241 & .000 & {$[1.108,1.390]$} \\
\hline Family history of depression & 1.299 & .000 & {$[1.126,1.498]$} & 1.589 & .000 & {$[1.399,1.805]$} \\
\hline Family relationships & 1.616 & .000 & {$[1.449,1.801]$} & 1.612 & .000 & {$[1.446,1.798]$} \\
\hline Social relationships & 1.573 & .000 & {$[1.419,1.743]$} & 1.532 & .000 & {$[1.378,1.703]$} \\
\hline Family support & 1.308 & .000 & {$[1.267,1.351]$} & 1.253 & .000 & {$[1.214,1.293]$} \\
\hline Perception of economic situation & 1.158 & .005 & {$[1.045,1.283]$} & 1.197 & .001 & {$[1.072,1.336]$} \\
\hline \multirow[t]{2}{*}{ Physical activity/intense exercise } & 1.433 & .000 & {$[1.275,1.610]$} & 1.329 & .000 & {$[1.198,1.474]$} \\
\hline & \multicolumn{3}{|c|}{$\begin{array}{c}\quad \chi^{2}=45.496, p \leq .05 \\
\text { Prediction: negative }=84.9 \% \text {, } \\
\text { positive }=45.6 \% \text {, total }=69.9 \%\end{array}$} & \multicolumn{3}{|c|}{$\begin{array}{c}\chi^{2}=19.32, p \leq .05 \\
\text { Prediction: } \text { negative }=84.2 \% \text {, } \\
\text { positive }=47.3 \% \text {, total }=69.9 \%\end{array}$} \\
\hline
\end{tabular}

sex, since depressive problems apparently have a specific structure and manifestation for women and men.

The psychosocial risk indicators for presenting a depressive disorder were similar for men and women: having suffered rape or sexual abuse, or severe insults and humiliations. However, certain psychosocial indicators have different importance for each sex: physical violence was a significant predictor among women, while the lack of spare time was solely among men. These results indicate that comorbidity and the effects of sexual and psychological abuse must urgently be addressed as antecedents for current depressive disorder among the young population (González-Forteza, Ramos Lira, Vignau Brambila, \& Ramírez Villarreal, 2001; Flannery, Wester, \& Singer, 2004) and highlight the importance of taking a gender-based approach to the phenomenon, as there is evidence that certain stressful events have a different effect on men and women (Bouma, Ormel, Verhusst, \& Oldehinkel, 2008).

The results of this paper concur with others in terms of the risk indicators for depressive disorder among young students: experience of abuse, poor quality of family and personal relationships, lack of physical activity, and family history of depression (Field, Diego, \& Sanders, 2001; MacPhee, \& Andrews, 2006; Aslund, Nilsson, Starrin, \& Sjoberg, 2007). Moreover, they show that the necessities detected and experienced by this population group must be treated (Frenk, Lozano, \& González, 1999) to give greater access to mental health services, which is a challenge in itself in particular for young people (Martínez-Hernáez, \& Muñoz García, 2010). The National Survey on Psychiatric Epidemiology (ENEP) (Borges, Wang, Medina-Mora, Lara, $\&$ Chiu, 2007) reported that Mexicans wait an average of 14 years before seeking treatment for affective disorders. This is the reason why it is an ethical and professional priority to offer the necessary facilities to shorten this breach, which increases the severity of depression and its consequences. Indeed, lack of treatment augments the emotional and social suffering, increases the costs and the delay to restore mental health and affects productivity. Additionally, it has a negative impact on academic performance and increases the likelihood of dropping out.

Studies like the one we present, which aim at dissecting and knowing the factors related to depression in young people, are relevant because they provide elements that could support the creation and implementation of specific interventions to reduce the negative impact of depressive symptoms. Likewise, the more detailed knowledge of the depressive disorder and its manifestations in women and men could generate modifications in the treatment of those who suffer from it, since the specificity of its expression requires focused therapeutic approaches.

Early detection of depressive disorder and identifying its psychological risk indicators are crucial tasks in achieving a better understanding of the complexity of depression and implementing suitable actions to prevent it; taking gender and other elements into account is fundamental to better ground interventions. Indeed, the risk indicators identified can be intrinsically related to the construction and performance of masculine and feminine qualities (Culbertson, 1997), in addition to the characteristics and necessities for the various circumstances of students at high school and college.

Depressive problems have a strong impact on global health systems; depression is one of the most disabling illnesses and its occurrence affects many persons globally. It also has a vast negative impact on the economy and the associated burden for health is considerable. Developing models for the interaction between the risk factors involved in depressive disorder supports the creation of cost-effective prevention strategies that reduce the relevance of dispositional factors and create scenarios that facilitate favorable interac- 
tions with the context. Preventive measures should address the social determinants of health, along with strategies to strengthen parenting skills, as well as help youth develop psychosocial resources to cope with stressful situations and manage emotions. Preventive interventions should include school-based initiatives aimed at helping youth to reduce risk for developing depressive symptoms. Universal interventions may be capable of shaping environments and individual behaviors simultaneously. School-based interventions may shape behavior, complimented with target educational interventions aiming at helping students build emotional and life skills, as well as the development of a variety of copying strategies.

Assessing the quality of services for preventing and treating mental health is an indispensable component of the intervention process. The ENEP (Borges et al., 2006) reported that only half the people $(51.2 \%)$ received treatment that qualified as "minimally adequate" in compliance with basic standardized guidelines, and because of this the challenge has yet to be completed. It is not enough to establish reference systems; accurate and regular quality monitoring strategies must be put into effect to adapt these systems to the requirements of youth's mental health, with emphasis on students, who are the object of significant social expectations. This must be understood within a dynamic process that requires the involvement of the healthcare services provided by institutions.

This study was carried out using data from two censuses among first year high school and college students. The results obtained allowed for a screening on the prevalence of depressive disorder. Moreover, given that this is a closed and entirely identified population group, of which there are registers, follow-up and prospective strategies and studies can be planned to test hypotheses on the variables most likely to indicate depressive disorder, and to assess the impact of several interventions.

One limitation of this work is that data on depressive disorder were obtained through a questionnaire whose items do not necessarily cover all the diagnostic criteria. The CES-D is a screening scale and the cases have yet to be confirmed using Golberg's two-stage model (Goldberg, 1972).

Another aspect to consider is that the evaluation of the screening was carried out during a moment of significant achievement in participants' lives: entering a new educational level. Thus, monitoring students, particularly at a time of academic pressure to move on to the next level or obtain a bachelor's degree, it is a necessity to detect and provide care before the school context stops being an opportunity to deal with their mental health.

\section{Funding}

Funding for this study was provided by the Universidad Nacional Autónoma de México (UNAM). The UNAM had no further role in study design, in the collection, analysis and interpretation of data, in the writing of the report, and in the decision to submit the paper for publication.

\section{Conflicts of interest}

The authors declare no conflicts of interest.

\section{Author's contribution}

Catalina González-Forteza, Alberto Jiménez Tapia, and Francisco Juárez García originated the idea for this study, did the research proposal, data analysis, interpretation of the data, and prepared the manuscript. Catalina González-Forteza and Cuauhtémoc Solís Torres. contributed to the research proposal, participated in the analysis, and in the manuscript preparation. Gisela Hernández Fernández participated in the interpretation of the data and in the discussion of the paper. Cuauhtémoc Solís Torres, Héctor Fernández-Varela, and María Elena Medina-Mora designed and conducted the original proposal and were involved in the preparation and discussion of the manuscript. All authors approved the final version.

\section{REFERENCES}

Adkins, D. E., Wang, V., Dupre, M. E., Van den Oord, E. J., \& Elder Jr, G. H. (2009). Structure and stress: Trajectories of depressive symptoms across adolescence and young adulthood. Social Forces, 88(1), 31-60. doi: 10.1353/sof.0.0238

Anda, R. F., Whitfield, C. L., Felitti, V. J., Chapman, D., Edwards, V. J., Dube, S. R., \& Williamson, D. F. (2002). Adverse childhood experiences, alcoholic parents, and later risk of alcoholism and depression. Psychiatric Services, 53(8), 1001 1009. doi: 10.1176/appi.ps.53.8.1001

Angold, A. (1988). Childhood and adolescent depression: I. Epidemiological and aetiological aspects. The British Journal of Psychiatry, 152(5), 601-617. doi: 10.1192/bjp.152.5.601

Angold, A., Erkanli, A., Silberg, J., Eaves, L., \& Costello, E. J. (2002). Depression scale scores in 8-17-year-olds: effects of age and gender. Journal of Child Psychology and Psychiatry, 43(8), 1052-1063. doi: 10.1111/1469-7610.00232

Aslund, C., Nilsson, K. W., Starrin, B., \& Sjoberg, R. L. (2007). Shaming experiences and the association between adolescent depression and psychosocial risk factors. European Child \& Adolescent Psychiatry, 16(5), 298-304. doi: 10.1007/ s00787-006-0564-1

Avanci, J. Q., Assis, S. G., \& Oliveira, R. V. (2008). Sintomas depressivos na adolescência: estudo sobre fatores psicossociais em amostra de escolares de um município do Rio de Janeiro, Brasil. Cadernos de Saúde Pública, 24(10), 23342346. doi: 10.1590/S0102-311X2008001000014

Benjet, C., Borges, G., Medina-Mora, M. E., Fleiz-Bautista, C., \& Zambrano-Ruiz, J. (2004). La depresión con inicio temprano: prevalencia, curso natural y latencia para buscar tratamiento. Salud Pública de México, 46(5), 417-424.

Benjet, C., Borges, G., Medina-Mora, M. E., Méndez, E., Fleiz, C., Rojas, E., \& Cruz, C. (2009). Diferencias de sexo en la prevalencia y severidad de trastornos psiquiátricos en adolescentes de la Ciudad de México. Salud Mental, 32(2), 155-163.

Borges, G., Medina-Mora, M. E., Wang, P. S., Lara, C., Berglund, P., \& Walters, E. (2006) Treatment and adequacy of treatment for mental disorders among respondents to the Mexico National Comorbidity Survey. American Journal of Psychiatry, 163(8), 1371-1378. doi: 10.1176/ajp.2006.163.8.1371

Borges, G., Wang, P. S., Medina-Mora, M. E., Lara, C., \& Chiu, W, T. (2007). Delay of first treatment of mental and substance use disorders in Mexico. American Journal of Public Health, 97(9), 1638-1643. doi: 10.2105/AJPH.2006.090985

Bouma, E. M, Ormel, J., Verhusst, F. C., \& Oldehinkel, A. J. (2008). Stressful life events and depressive problems in early adolescent boys and girls: The influence of parental depression, temperament and family environment. Journal of Affective Disorders, 105(1-3), 185-193. doi: 10.1016/j.jad.2007.05.007

Castillo-Manzano, R. M., \& Arankowsky-Sandoval, G. (2008). Violencia 
intrafamiliar como factor de riesgo para trastorno depresivo mayor en mujeres: Estudio de casos y controles. Revista Biomédica, 19(3), 128-133. doi: 10.32776/ revbiomed.v19i3.517

Chapman, D. P., Whitfield, C. L., Felitti, V. J., Dube, S. R., Edwards, V. J., \& Anda, R. F. (2004). Adverse childhood experiences and the risk of depressive disorders in adulthood. Journal of Affective Disorders, 82(2), 217-225. doi: 10.1016/j. jad.2003.12.013

Culbertson, F. M. (1997). Depression and gender: An international review. American Psychologist, 52(1), 25-31. doi: 10.1037/0003-066X.52.1.25

Field, T., Diego, M., \& Sanders, C. (2001). Adolescent depression and risk factors. Adolescence, 36(143), 491-498.

Flannery, D. J., Wester, K. L., \& Singer, M. I. (2004). Impact of exposure to violence in school on child and adolescent mental health and behavior. Journal of Community Psychology, 32(5), 559-573. doi: 10.1002/jcop.20019

Frenk, J., Lozano, R., \& González, M. A. (1999). Economía y salud: Propuesta para el avance del sistema de salud en México. [Economy and health: A proposal for the advancement of the health system.].

Fouilloux Morales, C., Barragán Pérez, V., Ortiz León, S., Jaimes Medrano, A., Urrutia Aguilar, M. E., \& Guevara-Guzmán, R. (2013). Síntomas depresivos y rendimiento escolar en estudiantes de Medicina. Salud Mental, 36(1), 59-65.

Ge, X., Conger, R. D., \& Elder Jr, G. H. (2001). Pubertal transition, stressful life events, and the emergence of gender differences in adolescent depressive symptoms. Developmental Psychology, 37(3), 404-417. doi: 10.1037/00121649.37.3.404

Goldberg, D. P. (1972). The detection of psychiatric illness by questionnaire: A technique for the identification and assessment of non-psychotic psychiatric illness. Oxford, England: Oxford University Press.

González-Forteza, C., Ramos Lira, L., Vignau Brambila, L. E., \& Ramírez Villarreal, C. (2001). El abuso sexual y el intento suicida asociados con el malestar depresivo y la ideación suicida de los adolescentes. Salud Mental, 24(6), 16-25.

González-Forteza, C., Solís Torres, C., Jiménez Tapia, A., Hernández Fernández, I., González-González, A., Juárez García, F., ... Fernández-Varela Mejía, H. (2011). Confiabilidad y validez de la escala de depresión CES-D en un censo de estudiantes de nivel medio superior y superior, en la Ciudad de México. Salud Mental, 34(1), 53-59.

Hankin, B. L. (2008). Cognitive vulnerability-stress model of depression during adolescence: Investigating depressive symptom specificity in a multi-wave prospective study. Journal of Abnormal Child Psychology, 36(7), 999-1014. doi: 10.1007/s10802-008-9228-6

Hasin, D. S., Goodwin, R. D., Stinson, F. S., \& Grant, B. F. (2005). Epidemiology of major depressive disorder: results from the National Epidemiologic Survey on Alcoholism and Related Conditions. Archives of General Psychiatry, 62(10), 1097-1106. doi: 10.1001/archpsyc.62.10.1097

IBM SPSS. (2010). IBM SPSS statistics base 19. Software User Guides, 330.

Jaureguizar, J., Bernaras, E., Soroa, M., Sarasa, M., \& Garaigordobil, M. (2015). Sintomatología depresiva en adolescentes y variables asociadas al contexto escolar y clínico. Behavioral Psychology/Psicología Conductual, 23(2), 245264.
Lenz, B. K. (2004). Tobacco, depression, and lifestyle choices in the pivotal early college years. Journal of American College Health, 52(5), 213-220. doi: 10.3200/JACH.52.5.213-220

MacPhee, A. R., \& Andrews, J. J. (2006). Risk factors for depression in early adolescence. Adolescence, 41(163), 435-466.

Martínez-Hernáez, A., \& Muñoz García, A. M. (2010). «Un infinito que no acaba». Modelos explicativos sobre la depresión y el malestar emocional entre los adolescentes barceloneses (España). Primera parte. Salud Mental, 33(2), 145152.

Martini, S., Wagner, F. A., \& Anthony, J. C. (2002). The association of tobacco smoking and depression in adolescence: evidence from the United States. Substance Use \& Misuse, 37(14), 1853-1867. doi: 10.1081/JA-120014087

Medina-Mora, M. E., Borges, G., Lara Muñoz, C., Benjet, C., Blanco Jaimes, J., Fleiz Buatista, C., ... Aguilar-Gaxiola, S. (2003). Prevalencia de trastornos mentales y uso de servicios: Resultados de la Encuesta Nacional de Epidemiología Psiquiátrica en México. Salud Mental, 26(4), 1-16.

Medina-Mora, M. E., Borges, G., Lara, C., Benjet, C., Blanco, J., Fleiz, C., ... Zambrano, J. (2005). Prevalence, service use, and demographic correlates of 12-month DSM-IV psychiatric disorders in Mexico: results from the Mexican National Comorbidity Survey. Psychological Medicine, 35(12), 1773-1783. doi: 10.1017/S0033291705005672

Milani, R. M., Parrott, A. C., Turner, J. J., \& Fox, H. C. (2004). Gender differences in self-reported anxiety, depression, and somatization among ecstasy/MDMA polydrug users, alcohol/tobacco users, and nondrug users. Addictive Behaviors, 29(5), 965-971. doi: 10.1016/j.addbeh.2004.02.044

Olfson, M., Marcus, S. C., Druss, B., Pincus, H. A., \& Weissman, M. M. (2003). Parental depression, child mental health problems, and health care utilization. Medical Care, 41(6), 716-721. doi: 10.1097/01.MLR.0000064642.41278.48

Poulin, C., Hand, D., Boudreau, B., \& Sandor, D. (2005). Gender differences in the association between substance use and elevated depressive symptoms in a general adolescent population. Addiction, 100(4), 525-535. doi: 10.1111/j.13600443.2005.01033.x

Radloff, L. S. (1977). The CES-D scale: A self report depression scale for research in the general population. Applied Psychological Measurement, 1(3), 385-401. doi: $10.1177 / 014662167700100306$

Reinherz, H. Z., Paradis, A. D., Giaconia, R. M., Stashwick, C. K., \& Fitzmaurice, G. (2003). Childhood and adolescent predictors of major depression in the transition to adulthood. The American Journal of Psychiatry, 160(12), 21412147. doi: 10.1176/appi.ajp.160.12.2141

Stata Corp LP. (2009). STATA Data Analysis and Statistical Software for Windows 11 [Software]. Texas: Stata Corp LP.

Twenge, J. M., Joiner, T. E., Rogers, M. L., \& Martin, G. N. (2018). Increases in depressive symptoms, suicide-related outcomes, and suicide rates among US adolescents after 2010 and links to increased new media screen time. Clinical Psychological Science, 6(1), 3-17. doi: 10.1177/2167702617723376

Wu, P., Hoven, C. W., Okezie, N., Fuller, C. J., \& Cohen, P. (2008). Alcohol abuse and depression in children and adolescents. Journal of Child \& Adolescent Substance Abuse, 17(2), 51-69. doi: 10.1300/J029v17n02_04 